\title{
HOME ENVIRONMENT AND FALL AT HOME AMONG THE ELDERLY IN MASJID TANAH PROVINCE
}

\author{
Rizawati M, Mas Ayu S \\ Department of Social and Preventive Medicine, Faculty of Medicine, University of Malaya, Kuala Lumpur.
}

\begin{abstract}
The aim of this study was to determine whether the home environment was a risk factor for falls occurring at home among the elderly in the Masjid Tanah community, Malaysia. An analytical cross-sectional study conducted from early June 2006 until May 2007 in six randomly selected villages in Masjid Tanah Province. A total of 516 participants were included in this study. Overall prevalence of falls among the study participants was $27.3 \%$. Home falls accounted for $66.7 \%$ of the total falls. In conclusion, there was no association between home environment and home fall in this study. Logistic regression analysis showed that having a depressive mood was the main determinant for home falls among the elderly in this study. (JUMMEC 2008; 11 (2): 72-82)
\end{abstract}

KEYWORDS: elderly, falls, home environment, risk factors

\section{Introduction}

Aging is inevitable and it is also known to be the most sensitive stage of one's life. Kazutomo defined aging as "regression of physiological function accompanied by advancement of age" (1). It is important to realize that aging is an irreversible process that occurs over a period of time. In the Policy for the Elderly in Malaysia, the elderly is defined as "the decrease in the ability of being in consistency with environmental factors" and the policy defines those above 60 years of age as old by adopting the criteria set at the First World assembly on Aging in Vienna in 1982 (2). Globally, older people make up a large and increasing percentage of the population. In 2000, there were about 600 million people aged 60 and above. It was estimated that in 2025 there will be 1.2 billion of elderly people and this will increase to 2 billion by 2050 (3). In almost every country in Asia the populations are aging. A country is said to be aging when at least $7 \%$ of the population are elderly (4). In Malaysia, the decline in fertility and mortality as well as improvement in life expectancy are said to be responsible for the ageing population by the year 2020. In Malaysia, currently, out of a population of 26 million (2005), 1.4 million (6.3\%) are aged over 60 years. It is projected to increase to 3.3 million out of 33 million (10\%) by 2020 (5).

Falls has been identified as one of the most prevalent public health problems facing older adults $(6,7)$. Around 40 to $60 \%$ of falls lead to injuries: 30 to $50 \%$ of these being minor injuries, $5-6 \%$ being major injuries excluding fractures and $5 \%$ being fractures $(8,9,10)$. Up to $1 \%$ of falls among the elderly resulted in hip fractures which has a significant morbidity, mortality and cost to health services $(8,9,11)$.

Studies had been done to investigate why the elderly fall and these have concluded that a combination of several factors contributed to a fall, including the presence of certain 'intrinsic' or 'extrinsic' factors $(11,12,13)$ which increased the risk of falls. Risk factors that have been identified include health status, medication use, impaired vision and hearing as well as environmental hazards. Information on occurrences of falls among the elderly and their associated risk factors in Malaysia are lacking. Furthermore, studies done in other countries showed that the role of environmental hazards in falls risk factors for elderly was uncertain. Investigation of the relationship between environmental hazards and falls in general population had shown mixed results $(14,15)$. However, it was noted that home environmental modifications had appeared to increase the effectiveness of multi-factorial interventions for reducing fall risk, and was recommended as part of a comprehensive fall prevention strategy $(16,17,18)$. Therefore, factors affecting falls among the elderly and

\section{Correspondance:}

Noor Rizawati Mahpot

Faculty of Medicine, University of Malaya

50603 Kuala Lumpur

Email:drriza_71@yahoo.com 
the occurrence of environmental hazards in our local setting should be investigated. The aims of this study were: (1) to determine the prevalence of overall falls and home falls among the elderly population in Masjid Tanah Province, in the state of Malaca, Malaysia (2) to explore the prevalence of environment hazards and other risk factors; and (3) to determine associations between home falls and these environment hazards.

\section{Methodology}

This was an analytical cross sectional study conducted from June 2006 until May 2007. The study started with a sampling of eligible study subjects from the target population. The participants were interviewed for history of fall at home and followed by home assessment to identify environmental hazards at home. This study was conducted in the Masjid Tanah Province. According to the village safety committee (JKKK) profile in 2006, the total population in this province was 15,956 people. Out of this, 11,892 were people above 65 years old (19). Main economic activities in this area are agriculture and tourism.

The target population in this study was all noninstitutionalized older people above 60 years who were living in the community of Masjid Tanah Province. The sampling method used in this study was two stages cluster sampling. In the first stage, six out of 12 villages (clusters) were randomly selected by drawing six sealed envelopes containing the villages' name from a box. All houses with eligible occupants, 60 years and above, were included at this stage. In the second stage, cluster was sampled based on the number of elderly occupants in each houses. The first cluster consisted of houses with single elderly occupant while the second cluster consisted of houses with more than one elderly occupant. The eligibility criteria was the elderly who were living in their homes or leasing similar accommodations and who consented to this study. The elderly were excluded if they were diagnosed with psychiatric illnesses or if they were bedridden or if they were not able to walk. Persons with physical lower limb deformity were also excluded.

The sample size calculation was carried out by using PS Power and Sample Size Programme version 2.1.31. The type I error rate (alpha) was fixed at 0.05 and power at $80 \%$. Previous studies showed that the prevalence of fall in elderly ranged from $20 \%$ (21) to $30 \%$ (21) and that the prevalence of home environmental hazards among the non-faller group was about 30\% (22). On the basis of this information, an estimated minimum sample size required in this study to detect a risk of 1.5 or greater for the fallers was 931 persons.

The dependent variable of interest in this study was a history of falls at home during the past 12 months. The definition for fall in this study was based on ICD 9 classification where "fall is an unexpected event where a person falls to the ground from an upper level or the same level" (23). This variable was determined during the interview. The perceived cause of fall and circumstances related to falls were determined from each faller.

The independent variable in this study was the presence of potential hazardous home environment in the participants' homes. This was also determined during the interview. Environmental hazards were defined as features of their homes or their residences that may contribute to a fall. Features such as poor lighting, slippery floors, clutter and handrails are part of the hazards that might have a role in causing falls among the elderly. The safety behaviors of the participants in the home environment were also considered as potential hazards. These components were determined by using two sets of screening tools. The Home-screen scale (HSS) was specifically designed as a nurse-administered instrument to identify environmental and behavioral risks that alert nurses to the need for action to reduce fall risks in the home (24). This instrument is a ten-item scale with two subscale categories: the home safe subscale and home behavior subscale. Each item was rated from 1 to 10 with intervals of 1 . A score of 10 represented that all rooms were free from clutter for the home safe subscale and safe for the home behavior. Total subscales score range from 5 to 100 . The safety house checklist (SHC) was adopted following a review of literature by Carter et al (25). This tool assessed the presence of hazards in each room or areas most frequently utilized by the elderly or in areas which they spend most of their time. Hazards which are thought to increase the risk of falling, slipping or tripping and the absence of safety devices which may prevent falls made up the majority of items in the house checklist. A decision was made about each item and a "hazard" scored if a potential hazard was present or a safety device was absent. If a hazard item area was not there to be assessed then the hazard 
item was scored as "not applicable." A hazard score was calculated for each home as well as for individual rooms and areas. The reliability of this checklist was assessed by means of kappa statistic which were adjusted for prevalence and bias and showed significant inter-rater agreement on all items (at $p=0.05$ ) (25). Other variables that were collected include the socio-demographic pattern, housing characteristics, medical conditions, medication, depressive mood, impaired cognitive function, decline in activities of daily living (ADLs), visual acuity, increased body mass index and impaired in balance and gait performance.

Permission to carry out the study was obtained from the relevant committee and departments, and from the participants. A face-to-face interview guided by a structured questionnaire was carried out on each participant. During the interview, socio-demographic information, medical and medication history, housing characteristics, occurrence and circumstances of falls events as well the Geriatric Depression scale 15 items (GDS 15), Elderly Cognitive Assessment Questionnaire (ECAQ) and Barthel index (BI) were completed. The home assessment was performed at the same setting. The physical assessment of participants was conducted within one week from the interview day in the nearby Health Clinic based on an appointment system. This assessment included measurements of weight, height and visual acuity as well as balance and gait test.

The completed questionnaires were double-checked for completeness at the end of every interview and physical assessment session as well as before storage. Incompleteinformation in the questionnaires especially on the physical examination variables (weight, height, BP and visual acuity) was obtained from available medical records from the nearest health clinics. Participants with no medical records available were re-invited to the nearest health centre for completion of these measurements. After completing the variables, data capturing was done using the Microsoft Excel software.

As this study design involved two stages of cluster sampling methods, Intercooled Stata statistical software version 9 was used for complex survey analysis. The analysis was performed in two stages. First, the frequency and prevalence of each variable was calculated. Second, univariate logistic regression analyses were carried out with home falls as the dependent variable and each of these variables as the independent variable. The results were presented as odds ratios (OR) with $95 \%$ confidence intervals (95\% Cls).

\section{Results}

\section{Study population}

Out of 1,049 people who were eligible, only 530 participated $(50.5 \%)$ in this study. The others either refused to participate or were not at home during the interview. Out of those 530 participants, 14 were excluded from the study, because two were bed bound, four were on wheelchair, three had either rays amputation or below knee amputation and five participants had incomplete home assessment. Thus, only 516 participants were included for analysis. A total of six villages were randomly selected in this study, namely Kampung Tanjung Bidara (200 elderly), Kampung Masjid Tanah (300 elderly), Kampung Durian Daun (89 elderly), Kampung Padang Kamunting (80 elderly), Kampung Pengkalan Balak (280 elderly) and Kampung Seri Tanjung (100 elderly). Sampling design and participants are summarized in Table 1.

\section{Socio-demographic distribution}

About $45 \%$ of the study population were between the age of 66 years and 75 years old, and $39 \%$ were between 60 and 65 years old, while another $16 \%$ were older than 75 years. The mean age of study participants was 68.7 years $(95 \% \mathrm{Cl} 67.9,69.6)$. Sixty-seven percent (67\%) of study population were female and only $33 \%$ were male. The majority of the elderly interviewed were Malays (98.3\%). Only a small proportion who were interviewed were Chinese (1.0\%) and Indians (0.7\%) in this study. More than half $(68.4 \%)$ of them had no formal education while only $31.6 \%$ received any form of formal education. Most of the participants were either unemployed or housewives (73.5\%), while small proportions were retired public servants $(16.7 \%)$, smallmedium industry entrepreneurs (6.0\%) and farmers/ fishermen (3.8\%). Their mean monthly household income was RM419.3 (95\%Cl RM321.5, RM517.0). Sixty percent $(60 \%)$ were married and another $40 \%$ were widowed, divorced or single. The majority of the participants stayed with their spouses $(57.4 \%)$, while $27.7 \%$ stayed with their own children. Another $3.5 \%$ of these elderly stayed with other relatives or friends and about $11.4 \%$ were living alone. It was noted that more 
Table 1: Distribution of Mean Age, Gender and Ethnicity of Study Participants by the Participating Villages, in Masjid Tanah Province ( $n=516)$

\begin{tabular}{|c|c|c|c|c|c|c|}
\hline Villages & $\begin{array}{c}\text { Kampung } \\
\text { Tanjung } \\
\text { Bidara } \\
\end{array}$ & $\begin{array}{c}\text { Kampung } \\
\text { Masjid } \\
\text { Tanah }\end{array}$ & $\begin{array}{c}\text { Kampung } \\
\text { Durian } \\
\text { Daun }\end{array}$ & $\begin{array}{c}\text { Kampung } \\
\text { Padang } \\
\text { Kamunting } \\
\end{array}$ & $\begin{array}{c}\text { Kampung } \\
\text { Pengkalan } \\
\text { Balak }\end{array}$ & $\begin{array}{c}\text { Kampung } \\
\text { Seri } \\
\text { Tanjung } \\
\end{array}$ \\
\hline Mean age* (years) & $\begin{array}{r}67.8 \\
{[66.5,69.2]}\end{array}$ & $\begin{array}{r}68.3 \\
{[67.9,68.8]}\end{array}$ & $\begin{array}{r}69.4 \\
{[68.7,70.2]}\end{array}$ & $\begin{array}{r}70.3 \\
{[68.7,71.6]}\end{array}$ & $\begin{array}{r}68.9 \\
{[68.0,69.8]}\end{array}$ & $\begin{array}{r}70.1 \\
{[69.1,71.2]}\end{array}$ \\
\hline $\begin{array}{l}\text { Gender* } \\
\text { Male }\end{array}$ & $\begin{array}{r}35.6 \\
{[28.3,43.7]}\end{array}$ & $\begin{array}{r}29.1 \\
{[23.2,35.8]}\end{array}$ & $\begin{array}{r}33.9 \\
{[21.3,49.3]}\end{array}$ & $\begin{array}{r}30.5 \\
{[17.3,47.9]}\end{array}$ & $\begin{array}{r}39.4 \\
{[30.7,48.9]}\end{array}$ & $\begin{array}{r}25.0 \\
{[15.5,37.6]}\end{array}$ \\
\hline Female & $\begin{array}{r}64.4 \\
{[56.3,71.7]}\end{array}$ & $\begin{array}{r}70.9 \\
{[64.2,76.8]}\end{array}$ & $\begin{array}{r}6.6 .1 \\
{[50.7,78.7]}\end{array}$ & $\begin{array}{r}69.5 \\
{[52.1,82.7]}\end{array}$ & $\begin{array}{r}60.6 \\
{[51.1,69.3]}\end{array}$ & $\begin{array}{r}75.0 \\
{[62.4,84.5]}\end{array}$ \\
\hline $\begin{array}{l}\text { Ethnicity* } \\
\text { Malays }\end{array}$ & $\begin{array}{r}98.9 \\
{[97.7,99.4]}\end{array}$ & $\begin{array}{r}97.3 \\
{[96.3,98.0]}\end{array}$ & 100 & $\begin{array}{r}98.3 \\
{[96.2,99.2]}\end{array}$ & $\begin{array}{r}97.8 \\
{[88.0,99.6]}\end{array}$ & 100 \\
\hline Chinese & 0 & $\begin{array}{r}0.9 \\
{[0.7,1.2]}\end{array}$ & 0 & $\begin{array}{r}1.7 \\
{[0.8,3.8]}\end{array}$ & $\begin{array}{r}2.2 \\
{[0.4,12.0]}\end{array}$ & 0 \\
\hline Indians & $\begin{array}{r}1.1 \\
{[0.6,2.3]}\end{array}$ & $\begin{array}{r}1.8 \\
{[1.3,2.5]}\end{array}$ & 0 & 0 & 0 & 0 \\
\hline $\begin{array}{l}\text { Marital status* } \\
\text { Single }\end{array}$ & $\begin{array}{r}1.1 \\
{[0.6,2.3]}\end{array}$ & 0 & 0 & 0 & 0 & 0 \\
\hline Married & $\begin{array}{r}57.5 \\
{[28.2,82.3]}\end{array}$ & $\begin{array}{r}57.3 \\
{[44.2,69.4]}\end{array}$ & $\begin{array}{r}74.6 \\
{[58.0,86.2]}\end{array}$ & $\begin{array}{r}54.2 \\
{[21.2,83.9]}\end{array}$ & $\begin{array}{r}66.4 \\
{[34.9,87.9]}\end{array}$ & $\begin{array}{r}51.6 \\
{[31.0,71.6]}\end{array}$ \\
\hline Divorced & 0 & $\begin{array}{r}0.9 \\
{[0.7,1.2]}\end{array}$ & $\begin{array}{r}1.7 \\
{[1.0,3.0]}\end{array}$ & $\begin{array}{r}1.7 \\
{[0.8,3.8]}\end{array}$ & 0 & $\begin{array}{r}1.6 \\
{[1.0,2.4]}\end{array}$ \\
\hline Widowed & $\begin{array}{r}41.4 \\
{[17.4,70.3]}\end{array}$ & $\begin{array}{r}41.8 \\
{[30.0,54.7]}\end{array}$ & $\begin{array}{r}23.7 \\
{[12.9,39.4]}\end{array}$ & $\begin{array}{r}44.1 \\
{[15.7,76.9]}\end{array}$ & $\begin{array}{r}33.6 \\
{[12.1,65.1]}\end{array}$ & $\begin{array}{r}46.9 \\
{[27.6,67.1]}\end{array}$ \\
\hline $\begin{array}{l}\text { Level of education* } \\
\text { None }\end{array}$ & $\begin{array}{r}37.9 \\
{[31.3,45.1]}\end{array}$ & $\begin{array}{r}31.8 \\
{[28.4,35.4]}\end{array}$ & $\begin{array}{r}13.6 \\
{[7.6,23.1]}\end{array}$ & $\begin{array}{r}40.7 \\
{[26.0,57.2]}\end{array}$ & $\begin{array}{r}32.8 \\
{[25.0,41.8]}\end{array}$ & $\begin{array}{r}21.9 \\
{[16.7,28.1]}\end{array}$ \\
\hline Primary & $\begin{array}{r}59.8 \\
{[51.7,67.3]}\end{array}$ & $\begin{array}{r}53.6 \\
{[46.6,60.6]}\end{array}$ & $\begin{array}{r}78.0 \\
{[63.2,87.9]}\end{array}$ & $\begin{array}{r}57.6 \\
{[40.0,73.5]}\end{array}$ & $\begin{array}{r}61.3 \\
{[52.6,69.4]}\end{array}$ & $\begin{array}{r}64.1 \\
{[55.2,72.1]}\end{array}$ \\
\hline Secondary & $\begin{array}{r}2.3 \\
{[1.1,4.6]}\end{array}$ & $\begin{array}{r}13.6 \\
{[10.0,18.3]}\end{array}$ & $\begin{array}{r}6.8 \\
{[3.8,11.7]}\end{array}$ & $\begin{array}{r}1.7 \\
{[0.8,3.8]}\end{array}$ & $\begin{array}{r}5.8 \\
{[3.5,9.5]}\end{array}$ & $\begin{array}{r}12.5 \\
{[9.2,16.8]}\end{array}$ \\
\hline Tertiary & 0 & $\begin{array}{r}0.9 \\
{[0.7,1.2]}\end{array}$ & $\begin{array}{r}1.7 \\
{[1.0,3.0]}\end{array}$ & 0 & 0 & $\begin{array}{r}1.6 \\
{[0.1,32.2]}\end{array}$ \\
\hline $\begin{array}{l}\text { Household income* } \\
\text { Mean total income (RM) }\end{array}$ & $\begin{array}{r}326.2 \\
{[261.6,390.7]}\end{array}$ & $\begin{array}{r}349.2 \\
{[334.2,364.1]}\end{array}$ & $\begin{array}{r}390.0 \\
{[352.3,427.7] .}\end{array}$ & $\begin{array}{r}412.3 \\
{[266.9,557.7]}\end{array}$ & $\begin{array}{r}551.9 \\
{[502.9,600.7]}\end{array}$ & $\begin{array}{r}490.4 \\
{[421.0,559.8]}\end{array}$ \\
\hline Less than RM500 & $\begin{array}{r}87.4 \\
{[80.3,92.2]}\end{array}$ & $\begin{array}{r}90.0 \\
{[86.5,92.6]}\end{array}$ & & $\begin{array}{r}81.4 \\
{[46.8,95.6]}\end{array}$ & $\begin{array}{r}68.6 \\
{[56.8,78.4]}\end{array}$ & $\begin{array}{r}82.8 \\
{[74.2,89.0]}\end{array}$ \\
\hline RM500-RM1000 & $\begin{array}{r}12.6 \\
{[7.8,19.7]}\end{array}$ & $\begin{array}{r}9.1 \\
{[6.7,12.2]}\end{array}$ & & $\begin{array}{r}16.9 \\
{[3.2,55.5]}\end{array}$ & $\begin{array}{r}27.0 \\
{[15.6,42.6]}\end{array}$ & $\begin{array}{r}12.5 \\
{[6.4,22.9]}\end{array}$ \\
\hline More than RM1000 & 0 & $\begin{array}{r}0.9 \\
{[0.7,1.2]}\end{array}$ & & $\begin{array}{r}1.7 \\
{[0.8,3.8]}\end{array}$ & $\begin{array}{r}4.4 \\
{[1.8,10.2]}\end{array}$ & $\begin{array}{r}4.7 \\
{[3.0,7.3]}\end{array}$ \\
\hline $\begin{array}{l}\text { Housing type* } \\
\text { Single storey }\end{array}$ & $\begin{array}{r}48.3 \\
{[37.4,62.1]}\end{array}$ & $\begin{array}{r}40.9 \\
{[35.2,46.9]}\end{array}$ & $\begin{array}{r}37.3 \\
{[27.7,48.0]}\end{array}$ & $\begin{array}{r}16.9 \\
{[7.2,35.0]}\end{array}$ & $\begin{array}{r}30.7 \\
{[19.5,44.7]}\end{array}$ & $\begin{array}{r}32.8 \\
{[24.1,42.9]}\end{array}$ \\
\hline Double storey & $\begin{array}{r}51.7 \\
{[37.9,65.3]}\end{array}$ & $\begin{array}{r}58.2 \\
{[52.1,64.0]}\end{array}$ & $\begin{array}{r}62.7 \\
{[52.0,72.3]}\end{array}$ & $\begin{array}{r}83.1 \\
{[65.0,92.8]}\end{array}$ & $\begin{array}{r}68.6 \\
{[55.2,79.5]}\end{array}$ & $\begin{array}{r}67.2 \\
{[57.1,75.9]}\end{array}$ \\
\hline Shops house & 0 & $\begin{array}{r}0.9 \\
{[0.7,1.2]}\end{array}$ & 0 & 0 & $\begin{array}{r}0.7 \\
{[0.3,1.7]}\end{array}$ & 0 \\
\hline $\begin{array}{l}\text { Living*arrangement } \\
\text { Spouse and children }\end{array}$ & $\begin{array}{r}55.2 \\
{[27.6,79.9]}\end{array}$ & $\begin{array}{r}54.5 \\
{[40.8,67.6]}\end{array}$ & $\begin{array}{r}52.5 \\
{[31.3,73.1]}\end{array}$ & $\begin{array}{r}55.9 \\
{[23.1,84.3]}\end{array}$ & $\begin{array}{r}66.4 \\
{[44.1,83.2]}\end{array}$ & $\begin{array}{r}50.0 \\
{[29.1,70.9]}\end{array}$ \\
\hline Children only & $\begin{array}{r}33.3 \\
{[16.4,56.1]}\end{array}$ & $\begin{array}{r}23.6 \\
{[17.2,31.5]}\end{array}$ & $\begin{array}{r}35.6 \\
{[21.7,52.5]}\end{array}$ & $\begin{array}{r}27.1 \\
{[11.0,52.9]}\end{array}$ & $\begin{array}{r}24.8 \\
{[14.0,40.1]}\end{array}$ & $\begin{array}{r}31.3 \\
{[19.2,46.5]}\end{array}$ \\
\hline Other & $\begin{array}{r}3.4 \\
{[1.7,6.9]}\end{array}$ & $\begin{array}{r}4.5 \\
{[3.4,6.1]}\end{array}$ & 0 & $\begin{array}{r}5.1 \\
{[2.2,11.1]}\end{array}$ & $\begin{array}{r}2.9 \\
{[1.2,6.8]}\end{array}$ & $\begin{array}{r}3.1 \\
{[2.0,4.9]}\end{array}$ \\
\hline Alone & $\begin{array}{r}8.0 \\
{[3.9,15.9]}\end{array}$ & $\begin{array}{r}17.3 \\
{[12.7,23.1]}\end{array}$ & $\begin{array}{r}11.9 \\
{[6.6,20.3]}\end{array}$ & $\begin{array}{r}11.9 \\
{[6.6,20.3]}\end{array}$ & $\begin{array}{r}5.8 \\
{[2.4,13.5]}\end{array}$ & $\begin{array}{r}15.6 \\
{[9.9,23.9]}\end{array}$ \\
\hline
\end{tabular}




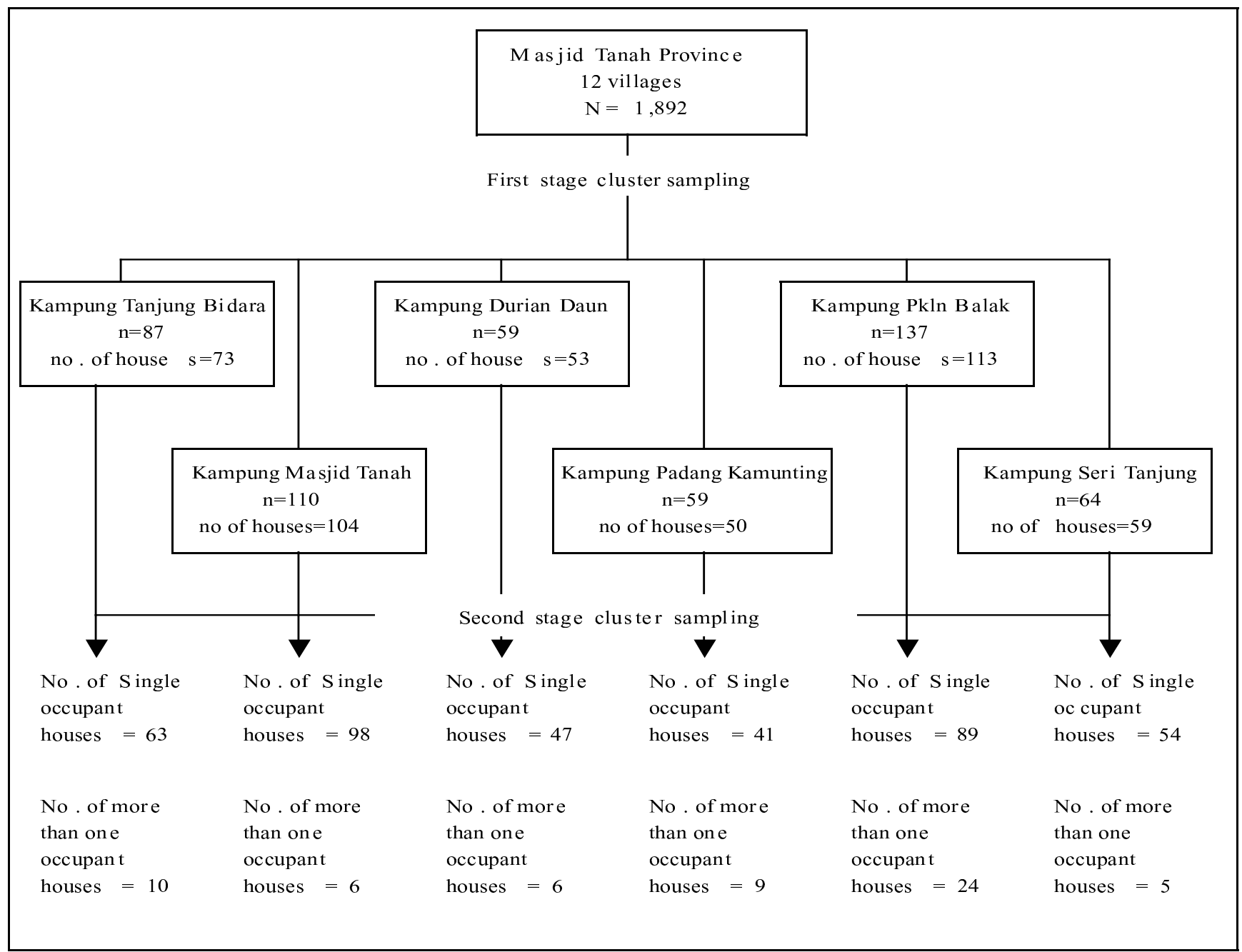

Figure 1: Summary of sampling design and participants

women (91.4\%) were living alone compared to men (8.6\%).

There were no significant variations in sociodemographic characteristics between the elderly studied in each village. This was demonstrated by the Wald Design-based $\mathrm{F}$ test which showed that the $p$ values were $>0.05$ for each characteristic (Table 1 ).

\section{Overall falls}

A total of 141 faller participants (27.3\%) reported 210 falls; $74.5 \%$ had experienced one episode of fall, $12.8 \%$ had two episodes of falls and another $12.8 \%$ had three or more falls in one year. Fall occurrence was highest in the younger elderly group (60-70 years) which accounted for $59.6 \%$ of total falls followed by the elderly in their 70's (32.7\%) and only $7.8 \%$ of elderly more than 80 years fell during the past 12 months. Women accounted for three quarters of the falls in this study. More than half $(55.3 \%)$ of these fallers did not suffer any injury and about $38.3 \%$ sustained mild or soft tissue injuries only, including, bruises, abrasions and haematoma. Only about $6.4 \%$ of them sustained either joints dislocations or fractures. No information on utilization of medical facilities or hospitalization were gathered. On exploring the perceived cause of falls among the participants, 39\% perceived their fall events was due to having slipped, $25.5 \%$ due to being tripped and another $17.0 \%$ of falls occurred due to bodily imbalance. Giddiness and weakness of lower limbs were thought to be the cause for falling by $7.1 \%$ and $3.5 \%$ of participants respectively. Most falls occurred in the evening (40\%) and at night (19.9\%) followed by at dawn (16.3\%) and in the morning (6\%). Another small proportion of fallers were unable to remember the circumstances that led to their falls. In this study, it was found that most falls occurred inside the homes $(66.7 \%) ; 19.1 \%$ outdoors and another $14.2 \%$ occurred while away from their homes and surroundings. For further evaluation of the relationship 
Table 2: Crude Odds Ratio for the association between study characteristics with home falls among the elderly in Masjid Tanah Province

\begin{tabular}{|c|c|c|c|c|}
\hline \multirow{2}{*}{ Characteristics } & \multicolumn{2}{|c|}{ Home Falls $(n=516)$} & \multirow{2}{*}{ Crude OR } & \multirow{2}{*}{$95 \% \mathrm{Cl}$} \\
\hline & Yes & No & & \\
\hline \multicolumn{5}{|l|}{ Age } \\
\hline 60-65years* & 0.24 & 0.76 & 1.0 & - \\
\hline $66-75$ years & 0.25 & 0.75 & 1.1 & {$[0.7,1.8]$} \\
\hline More than 75 years & 0.27 & 0.27 & 1.2 & {$[0.6,2.5]$} \\
\hline \multicolumn{5}{|l|}{ Gender } \\
\hline Male* & 0.19 & 0.81 & 1.0 & - \\
\hline Female & 0.28 & 0.72 & 1.7 & {$[0.9,2.9]$} \\
\hline \multicolumn{5}{|l|}{ Ethnicity } \\
\hline Malays* & 0.25 & 0.75 & 1.0 & - \\
\hline Chinese & 0.48 & 0.52 & 1.1 & {$[0.1,22.2]$} \\
\hline Indians & 0.54 & 0.46 & 1.6 & {$[0.4,6.1]$} \\
\hline \multicolumn{5}{|l|}{ Marital status } \\
\hline Married* & 0.23 & 0.77 & 1.0 & - \\
\hline Widow/Single/Divorced & 0.29 & 0.71 & 1.4 & {$[0.7,2.5]$} \\
\hline \multicolumn{5}{|l|}{ Education level } \\
\hline None & 0.26 & 0.74 & 1.1 & {$[0.4,2.5]$} \\
\hline Primary & 0.24 & 0.76 & 0.9 & {$[0.3,3.1]$} \\
\hline Tertiary/Secondary* & 0.26 & 0.74 & 1.0 & - \\
\hline \multicolumn{5}{|l|}{ Total household income } \\
\hline Less than RM500 & 0.27 & 0.73 & 3.3 & {$[0.7,15.3]$} \\
\hline RM500-RM1000 & 0.21 & 0.79 & 2.3 & {$[0.5,10.9]$} \\
\hline More than RM1000* & 0.098 & 0.90 & 1.0 & - \\
\hline \multicolumn{5}{|l|}{ Living arrangements } \\
\hline Spouse and children* & 0.23 & 0.77 & 1.0 & - \\
\hline Children only & 0.28 & 0.72 & 1.3 & {$[0.7,2.3]$} \\
\hline Alone & 0.26 & 0.74 & 2.6 & {$[0.7,9.5]$} \\
\hline Others & 0.44 & 0.56 & 1.2 & {$[0.6,2.4]$} \\
\hline Diabetes mellitus & 0.26 & 0.73 & 1.1 & {$[0.7,1.6]$} \\
\hline Hypertension & 0.25 & 0.75 & 0.9 & {$[0.5,1.8]$} \\
\hline Heart disease & 0.29 & 0.71 & 1.2 & {$[0.4,3.4]$} \\
\hline Epilepsy & 0.38 & 0.62 & 1.8 & {$[0.4,7.8]$} \\
\hline Stroke & 0.33 & 0.67 & 1.5 & {$[0.6,3.8]$} \\
\hline Knee osteoarthritis & 0.34 & 0.66 & 1.6 & {$[0.9,3.1]$} \\
\hline \multicolumn{5}{|l|}{ Medication } \\
\hline Less than 4 types & 0.27 & 0.73 & 1.1 & {$[0.5,2.3]$} \\
\hline More than 4 types & 0.23 & 0.77 & 0.9 & {$[0.4,2.2]$} \\
\hline Depressive mode & 0.33 & 0.67 & 1.9 & {$[1.1,3.3]$} \\
\hline \multicolumn{5}{|l|}{ Cognitive function } \\
\hline Borderline case & 0.32 & 0.68 & 1.6 & {$[0.8,3.4]$} \\
\hline Probable case & 0.34 & 0.66 & 1.8 & {$[0.9,3.7]$} \\
\hline \multicolumn{5}{|l|}{ Activity daily living } \\
\hline Need assistance & 0.20 & 0.80 & 0.7 & {$[0.2,2.4]$} \\
\hline \multicolumn{5}{|l|}{ Body mass index (BMI) } \\
\hline Underweight & 0.27 & 0.73 & 1.1 & {$[0.7,1.7]$} \\
\hline Overweight & 0.25 & 0.75 & 0.9 & {$[0.6,1.6]$} \\
\hline
\end{tabular}


between home environment and other independent characteristics with occurrence of fall, only home falls were considered in the analysis.

\section{Home falls}

In this study, home falls were defined as a history of fall which had occurred inside and in the immediate surroundings of the elderly's home within the past 12 months. It was found that the prevalence of home falls among the elderly in this study was $25.1 \%$. Home falls occurred more commonly in females (66.8\%) than in males (33.2\%) and most home fallers were in the age range of 60-70 years old (54.3\%). Within the home, falls commonly occurred in the living room/hallway (33.9\%), bathroom/toilet (29.9\%), dining room/kitchen (12.7\%) and bedroom (3.1\%) while outdoor falls accounted for only about $20.4 \%$.

\section{Home environment}

In this study, the home environment was assessed by using two instruments.

\section{Home screen scale (HSS)}

In the home safe subscale, the characteristics of five hazards were assessed. Based on the cut-off points of each subscale items at the 25th percentile of this study population, it was found that about $19.4 \%$ of houses had unsafe clutter present and $16.2 \%$ had unsafe floor covering, at least in one of the areas assessed. Inadequate daylight illumination was observed in $30.5 \%$ of the homes, while $19.3 \%$ homes had insufficient night lighting. It was also found that $21.5 \%$ of these elderly homes had hazards present in their toilet. Further analysis to look for the association between home environment and study characteristics found that mean age $(p=0.01)$ and cognitive function $(p=0.014)$ were significantly associated with the presence of hazards in the home environment. This step was performed in order to look for possible confounders statistically.

\section{Safety house checklist (SHC)}

This scale was designed to look for hazards in specific areas used most frequently by the elderly inside their homes. From all the areas observed, the bathroom was the most common site which has at least one hazard. This was found in nearly $40 \%$ of the homes visited. The other sites that were surveyed were the hallway, the living room, the dining room, and the kitchen. Thirteen percents $(13.0 \%), 8.3 \%, 9.4 \%$ and $12.8 \%$ of homes were found to have at least one hazard in each area respectively. It was also noted that in about $4 \%$ of these homes the bedrooms occupied by the participants were hazardous.

\section{Risk factors for home falls}

Table 2 describes the relationship between study variables and home falls among the elderly.

\section{Home environment and home falls}

Crude and adjusted association between home environment and home falls among the study participants are shown in Table $2 \mathrm{a}$ and $2 \mathrm{~b}$. Based on the home safe subscale of home screen scale (HSS), there was no association between falls at home and the home environment. The crude odds ratio was 1.0. The odds ratio adjusted for age, gender, depressive mood and cognitive function remains insignificant (Table 2a).

The same relationship was also observed when the safety house checklist scale was used to classify home environment. The classification was based on the cutoff value at the 75th percentile of the study population composite score. Houses with a total score of more or

Table 2a: Relationship Between Home Fall Among the Elderly and Home Environment Based on Home Safe Subscale of HSS (Johnson M et. al. 2001) $n=516$

\begin{tabular}{|c|c|c|c|c|}
\hline \multirow{2}{*}{ Home environment } & \multicolumn{2}{|c|}{ Home falls } & \multirow{2}{*}{$\begin{array}{c}\text { Crude OR } \\
{[95 \% \mathrm{CI}]}\end{array}$} & \multirow{2}{*}{$\begin{array}{c}\text { Adjusted OR } \\
\text { [95\%Cl]* }\end{array}$} \\
\hline & Yes & No & & \\
\hline Potential hazardous (score $<=40$ ) & $24.6[13.7,40.3]$ & $75.4[59.7,86.3]$ & \multirow{2}{*}{$\begin{array}{c}1.0 \\
{[0 . .3,2.8]}\end{array}$} & \multirow{2}{*}{$\begin{array}{c}1.0 \\
{[0.4,2.7]}\end{array}$} \\
\hline Safe (score >40) & $25.2[15.5,38.1]$ & $74.8[61.9,84.5]$ & & \\
\hline
\end{tabular}


equal to six was categorized as potentially hazardous. It was found that there was an association between home environment and home falls (OR 1.1, 95\% Cl $0.9,1.2)$. However, this relationship was not significant (Table 2b).

Further exploration of the individual elements of home environment assessed in the study with occurrences of home falls found that for exposure to more or equal to one hazards per room, the odds ratio adjusted for age, gender, depressive mood and cognitive function were $2.1(95 \% \mathrm{Cl} 1.1,4.0)$ for the bedroom, $1.4(95 \% \mathrm{Cl}$ $1.1,2.1)$ for the bathroom, $1.1(95 \% \mathrm{Cl} 0.6,1.7)$ for the kitchen, $1.1(95 \% \mathrm{Cl}, 0.3,4.9)$ for the living room, and $0.5(95 \% \mathrm{Cl} 0.1,2.7)$ for the hallway.

\section{Discussion}

\section{Background characteristics of study population}

In this study, almost all the participants were Malays (98.3\%) while Chinese and Indians were represented by small proportions of $1.0 \%$ and $0.7 \%$, respectively. The proportion of contributions by ethnic group differs from the background population. However, this distribution was closer to the ethnics' distribution of each selected village (cluster) where most Chinese and Indians were found in areas with economic activities and in town areas for example, in Kampung Masjid Tanah and Kampung Pengkalan Balak. The rest of the clusters were mostly Malay rural residential areas (19). More females were interviewed in this study. This was reflective of the gender distribution of older people in Masjid Tanah where 54\% of elderly above 65 years were females (19). Furthermore, it was reported that women tend to live longer than men, so the disproportion between males and females also increased with ageing (5). It was also noted that this group of participants had never received any formal education (68.4\%). This was similar to the national elderly population's pattern of education level. A review on national policies and program has reported that the present cohort of Malaysian older persons are not well educated (1991 (ensus) due to the limited educational opportunities during the nation's economic development in the early decades of the twentieth century. Some $63 \%$ of older persons had not received any formal education at all (26). Findings suggested that more women were living alone than men. This finding was similar to the study done by Davis MA et al among 7,651 adults, aged 45 to 74 years in the National Health and Nutrition Examination Survey (NHANES I) in the United States (27). They found that the proportion of women who were living alone were higher than men and for women, this proportion increased with age.

\section{Occurrences and consequences of falls}

The prevalence of falls in this study was found to be much lower than occurrences reported by the Western studies $(6,21,28,29)$. This could be due to the fact that older people were often reluctant to report falls occurrences or that they simply forgot about the events.

A part of studying falls would not be complete without the consideration of fall sequels. Only types of injuries were captured in this study, the prevalence of needing medical attention and hospitalization were not captured. Falls had other consequences besides injuries. Long periods of being bedridden and fear of falling were common consequences that needed further consideration.

\section{Home environment and home falls}

In the whole group, the presence of home hazards did not increase the risk of falls during the past 12 months. After an adjustment for possible confounders (age, gender, depressive mood and cognitive function),

Table 2b: Relationship Between Home Fall Among the Elderly and Home Environment Based on Safety House Checklist (Carter E et al 1997$) n=516$

\begin{tabular}{|c|c|c|c|c|}
\hline \multirow{2}{*}{ Home environment } & \multicolumn{2}{|c|}{ Home falls } & \multirow{2}{*}{$\begin{array}{c}\text { Crude OR } \\
{[95 \% \mathrm{Cl}]}\end{array}$} & \multirow{2}{*}{$\begin{array}{c}\text { Adjusted OR } \\
{[95 \% \mathrm{Cl}]^{*}}\end{array}$} \\
\hline & Yes & No & & \\
\hline Potential hazardous (score > $=6$ ) & $26.6[16.2,40.4]$ & $73.4[59.6,83.8]$ & \multirow{2}{*}{$\begin{array}{c}1.1 \\
{[0.5,2.7]}\end{array}$} & \multirow{2}{*}{$\begin{array}{c}1.1 \\
{[0.9,1.2]}\end{array}$} \\
\hline Safe $($ score $<6)$ & $24.7[15.9,36.3]$ & $75.3[63.7,84.1]$ & & \\
\hline
\end{tabular}

Key: row percentages [95\% confidence intervals for row percentages]

*Adjusted for age, gender, depressive mood and cognitive function 
there was no change of risk. This could be due to that "variable" home hazards might have been eliminated or changed before the home assessment was performed. Furthermore, this study collected retrospective history of home falls. It has been shown that hazards were removed or changed following a fall (30). Another possibility for this lack of association was inadequate power of the study. Retrospective calculation revealed that this study was only $54 \%$ powered.

\section{Risk factors for home falls}

This study demonstrated that having depressive symptoms was a significant risk factor for fall among the elderly. This was also consistent with many other studies $(31,32,33,34)$. The risk increased from $50 \%$ to almost three-fold from the non-depressed elderly. This variation reflects the methodological difference in study design, sample size, study population, duration of assessment as well as the study instruments used in the various studies.

\section{Limitations}

The results in this study could possibly be subjected to selection bias as not all of the elderly in the selected cluster participated in this study. This was due to the fact that the interview was performed mainly during the daytime when most of the elderly were not at home. In addition, some elderly had refused to participate in this study. This would also contribute to the issue of lack of evidence of generalizability. As the true reasons for non-response could not be investigated and the characteristics were not determined, it was unclear as to what extent the sample studied is representative of the whole elderly population.

This study relied on self report of falls, which was known to have some systematic reporting bias because of retrospective recall. This was supported by Cumming et al where they reported that $13 \%$ to $32 \%$ of older adults who had fallen previously have forgotten about their falls (15).

\section{Recommendations}

Multiple risk factors were found to have associated with fall. These risk factors could be assessed simply, briefly and inexpensively in primary care setting. High risk patients could be advised to participate in a multi-factorial intervention program or they could be referred to a physicians or physiotherapists to optimize their medical and physical conditions.

\section{Conclusions}

There was no association between home environment and home falls in this study. However, further analysis found that hazards present in bedroom and bathroom would increase the likelihood of home falls two fold and $40 \%$ of the elderly, respectively. Logistic regression analysis showed that having a depressive mood was the main determinant for home fall among the elderly in this study.

\section{Acknowledgements}

The authors would like to express their gratitude to staff from Alor Gajah District Health Office, Masjid Tanah Health Center and University of Malaya's Institute of Research Management and Consultancy for providing the research grant for the study.

\section{References}

1. Kazumoto I. How I understand aging. Nutr Rev 1992; 50(12):351-352.

2. Ministry of National Unity and Social Development, Malaysia. Policy for the Elderly; 1996.

3. World Health Organization. Ageing and life course. The world is fast aging- Have we noticed? Geneva. World Health Organization; 2002.

4. Haub C. World population prospects, United Nation. Consequences Vol. 1, No. 2, Summer 1995. http:// www.gcrio.org/CONSEQUENCES/summer95/ population.html. Accessed on December 2005.

5. Mafauzy M. The problems and challenges of the aging population of Malaysia. Malaysian J of Med Sciences 2000; 7:1-3.

6. WHO Europe Report by Health Evidence Network on what are the main risk factors for falls amongst older people and what is the most effective intervention to prevent this fall? How intervention to prevent falls should be implemented. World Health Organization; March 2004.

7. Tinetti ME. Clinical Practice. Preventing falls in elderly persons. N Eng J Med 2003, 348:42-49. 
8. Sattin RW, Huber DA, deVito CA, et al. The incidence of fall injury events among the elderly in a define population. Am J Epidemiol 1990;131:1028-1037.

9. Tinetti ME, William C. Falls, injuries due to falls, and the risk of admission to a nursing home. $N$ Engl J Med 1997; 337: 1279-1284.

10. Masud T and Morris R. Epidemiology of falls. Age and ageing 2001, 30- S4; 3-7.

11. Tinetti ME, Speechly M, Ginter SF. Risk factors for falls among elderly person living in the community. N Engl J Med 1988; 319:1701-1707.

12. Assantachai $P$, Praditsuwan $R$, Chattanawaree W. et al. Risk factors for falls in the Thai urban community. J Med Assoc Thai 2003; 86:124-130.

13. Connell BR. Role of the environment in fall prevention. Clin Geriatr Med 1996; 12:859-880.

14. Northridge ME, Nevitt MC, Kelsy JL, Link B. Home hazards and falls in the elderly: the role of health and functional status. Am J Publ Health 1995; 85:509-514.

15. Cumming RG. Home visit by an occupational therapist for assessment and modification of environmental hazards. A randomized trial of fall prevention. J Am Geriatr Soc 1999; 47(12):13971402.

16. Gillespie LD, Gillespie WJ, Robertson MC, Lamb SE, Rowe $\mathrm{BH}$. Interventions for preventing fall in elderly people. The Cochrane database of Systematic reviews 2003, issues 4 . Internet communication at art no.: CD 000340. DOI: 10.1002/14651858. CD000340.

17. Feder $\mathrm{G}$ et al. Guidelines for the prevention of falls in older people. BMJ 2000; 321: 1007-1011.

18. Schwartz AV, HillierTA, Sellmeyer DE et al. Older women with diabetes have higher risk of falls. Diabetes Care 2002; 25:1749-1754.

19. Masjid Tanah population statistics and profile. DUN Masjid Tanah Village Safety Committee (Jawatan Kuasa Keselamatan Kampung), Malaysia; 2006. (Unpublished data)

20. Chu LW, Chi I, Chiu AYY. Incidence and predictors of falls in the Chinese elderly. Ann Acad Med Singapore $2005 ; 34: 60-72$.
21. Nevitt MC, Cummings SR, Kidd S, et al. Risk factors for recurrent non syncopal falls. JAMA 1989; 18: 2663-2668.

22. Gill TM, Williams CS, Robinson JT, et al. Population based study of environmental hazards in the home of older persons. Am J Publ Health 1999; 89:553556.

23. WHO. Manual of the international classification of diseases, injuries, and causes of death. 9th revision, 1977; Vol.1.

24. Johnson M, Cusick, Chang S. Home-Screen: A short scale to measure fall risk in the Home. Publ Health Nurs 2001; 18(3): 169-177.

25. Carter E, Campbell E, Sanson-Fisher R, et al. Environmental hazards in the homes of older people, age and ageing 1997; 26:195-202.

26. Ong FS. Ageing in Malaysia A Review of National Policies and Programmes. http://www.idrc.ca/ awards/ev.htm. Accessed on 11th February 2006.

27. Davis MA, Neuhaus JM, Moritz DJ, et al. Living arrangements and survival among middle aged and older adults in the NHANES I epidemiologic follow up study. Am J Publ Health 1992; 82: 401406.

28. Schiller JS, Kramarow EA, Dey AN. Fall injury episodes among noninstitutionalized older adults: United States, 2001-2003. Advance data from vital and health statistics; no 392 . Hyattsville, MD: National Center for Health Statistics; 2007.

29. Halter M, Close JC, Elrick A, Brain G, Swift C. Falls in the Older Population: A Pilot study to assess those individuals who are attended to by the London Ambulance Service as a result of a fall but are not conveyed to an Accident and Emergency Department. London: London Ambulance Service NHS Trust; 2000.

30. Clemson L, Cumming RG; Roland M. Case-control study of hazards in the home and risk of falls and hip fracture. Age Ageing 1996; 25: 97-101.

31. Pluijm SM, Smit JH, Tromp EA, et al. A risk profile for identifying community dwelling elderly with a high risk of recurrent falling: Results of a 3-year prospective study. Osteoporosis Int 2006; 17:417425. 
32. Biderman A, Cwikel J, Fried AV, et al. Depression and falls among community dwelling elderly people: a search for a common risk factors. $J$ Epidemiol Community Health 2002; 56: 637-636.

33. Stalenhoef PA, Deaderiks JP, Knottnerus JA, et al. $A$ risk model for prediction of recurrent falls in community dwelling elderly: A Prospective cohort study. J Clin Epidemiol 2002; 55:1088-1094.

34. Stalenhoef PA, Diedriks JP, Knottnerus JA, et al. The construction of a patient record based risk model for recurrent falls among elderly people living in the community. Fam Pract 2000; 17:490-496. 